\title{
Pola Pemanfaatan Aplikasi Media Belajar dan Kualitas Interaksi Pembelajaran Online Mahasiswa Institut Agama Kristen Negeri Tarutung
}

\author{
Erika Christine Panggabean $^{1}$, Soemedi Hadiyanto ${ }^{2}$ \\ ${ }^{1}$ Institut Agama Kristen Negeri Tarutung, Tapanuli Utara, Indonesia \\ ${ }^{2}$ Balai Latihan Tenaga Kesehatan Provinsi Papua, Jayapura, Indonesia \\ Email: erika.panggabean@gmail.com/soemedihadiyanto@gmail.com
}

\begin{abstract}
ABSTRAK
Kualitas dan efektifitas pembelajaran online di era pandemi Covid-19 tergantung pada pemanfaatan aplikasi media belajar dan kualitas interaksi pembelajaran online. Metode penelitian kuantitatif deskriptif. Populasi 2.334 mahasiswa dan sampel 440 mahasiswa. Alat pengumpulan data adalah daftar pertanyaan, pengumpulan data bulan November-Desember 2020. Analisis data meliputi perhitungan rerata, persentase, penyajian grafik dan tabel dengan SPSS versi 25.0 for windows. Hasil; pola penggunaan handphone/smartphone sebagai perangkat media belajar online dominan dan sebaliknya penggunaan laptop/komputer rendah dan pembelajaran online dilakukan dari rumah sendiri/orangtua. Penggunaan zoom meeting belum familiar oleh mahasiswa dibandingkan aplikasi whatsapp group. Persepsi mahasiswa terhadap kualitas kuliah/belajar online baik $(78,18 \%)$, hal ini disebabkan karena interaksi antar pengajar-mahasiswa dan pemahaman dalam pembelajaran/ perkuliahan online baik. Tetapi sebaliknya persepsi mahasiswa terhadap kemudahan dan kesan belajar/kuliah online cukup rendah sebab pola pelaksanaan masih dominan dilakukan dengan cara tunggal yaitu hanya melakukan penjelasan online langsung atau berdiskusi pada forum/chat group atau memberikan tugas baca atau memberikan referensi video.
\end{abstract}

Kata Kunci: aplikasi media online, evaluasi pembelajaran, kualitas interaksi, persepsi mahasiswa.

\section{PENDAHULUAN}

Pandemi Corona Virus 19 (Covid-19) yang terdeteksi di Indonesia pada tanggal 2 Maret 2020 dengan 2 kasus, telah menyebar dengan sangat cepat ke 34 provinsi pada tanggal 9 April 2020, terutama di Provinsi Jawa Timur, DKI Jakarta dan Sulawesi Selatan. Pemerintah kemudian melakukan pembatasan pergerakan di segala aspek sehingga mempengaruhi berbagai sektor publik terutama ekonomi, pelayanan kesehatan dan penyelenggaraan Pendidikan (Muhyiddin, 2020). Penyelenggaraan pendidikan dengan metode tatap muka (face to face) di semua jenjang kemudian dihentikan dan dialihkan ke pembelajaran elektronik (electronic learning) atau e-learning yang dilaksanakan secara online (Anugrahana, 2020). Institut Agama Kristen Negeri (IAKN) Tarutung Kabupaten Tapanuli Utara kemudian turut menghentikan pembelajaran konvensional (face to face) tersebut dan beralih ke alternatif pembelajaran online/daring.

Pembelajaran daring/online memerlukan media media belajar untuk memudahkan dosen/staf pengajar dalam memberikan materi pembelajaran dan diskusi jarak jauh, serta memudahkan mahasiswa untuk mengunduh materi maupun melakukan diskusi dengan dosen/staf pengajar (Sadikin dan Hamidah, 2020). Media belajar tersebut misalnya Google Classroom, Edmodo dan Schoology (Iftakhar, 2016), WhatsApp (So, 2016), Facebook dan Instagram (Kumar dan Nanda, 2019). Interaksi langsung mahasiswa dengan dosen/staf pengajar dapat dilakukan melalui zoom meeting tetapi memboroskan kuota dan berbiaya tinggi serta kurang efektif apabila dengan jumlah peserta banyak (Naserly, 2020). Pada 
daerah tertentu terutama di pegunungan, terkendala internet yang lemah dan cara penyampaian dosen/staf pengajar yang sulit dipahami (Astuti dan Febrian, 2019).

Permasalahan terkait dengan aplikasi media belajar, interaksi, kualitas dan hambatan perkuliahan daring/online belum pernah dilakukan penelitian di IAKN Tarutung. Penelitian Adijaya dan Santosa (2018) di Jakarta hanya membahas variabel interaksi mahasiswa dan lingkungan belajar online dan penelitian Maulana dan Hamidi (2020) di Bengkalis hanya membahas variabel proses belajar mengajar, kapabilitas (kompetensi dosen) serta sarana dan prasarana.

Pertanyaan penelitian ini adalah bagaimanakah pemanfaatan aplikasi media belajar daring/online? dan bagaimanakah interaksi, kualitas dan hambatan perkuliahan daring/online? Penelitian bertujuan mengkaji pemanfaatan aplikasi media belajar daring/online; dan mengkaji interaksi, kualitas dan hambatan perkuliahan daring/online mahasiswa pada masa pandemi Covid 19. Hasil penelitian ini diharapkan dapat menjadi acuan dalam peningkatan mutu dan bahan penyusunan perencanaan pembelajaran daring/online pada masa pandemi Covid 19 di IAKN Tarutung.

\section{METODE PENELITIAN}

Penelitian kuantitatif dan disajikan secara deskriptif pada mahasiswa IAKN Tarutung Kabupaten Tapanuli Utara Provinsi Sumatera Utara. Jarak antara Medan ibukota Provinsi Sumatera Utara ke Kota Tarutung yang merupakan daerah pegunungan adalah $294 \mathrm{~km}$ yang dapat ditempuh selama 6 jam lewat darat. Populasi adalah 2.334 mahasiswa dan sampel adalah 440 mahasiswa $(18,85 \%)$ yang mengisi daftar pertanyaan pada website. Alat ukur penelitian menggunakan daftar pertanyaan tertutup terstruktur dengan dengan model skala Likert, yang diisi melalui google form dengan link https://forms.gle/t29nBJBKfVLN WCJN6. Pengumpulan data dilaksanakan selama bulan November hingga Desember 2020. Analisis data meliputi frekuensi pendistribusian sampel berdasarkan variabel, perhitungan rerata, persentase, penyajian grafik dan tabel dengan SPSS (Statistical Package for Social Sciences) versi 25.0 for windows (Santoso, 2019).

\section{HASIL DAN PEMBAHASAN}

Sampel penelitian berjumlah 440 mahasiswa terdiri dari 101 laki-laki $(23,00 \%)$ dan 339 perempuan $(77,00 \%)$, berasal dari Program Studi Pendidikan Kristen sebanyak 212 mahasiswa (48,20\%), Program Studi Teologi sebanyak 53 mahasiswa (12,00\%), Program Studi Manajemen Pendidikan sebanyak 39 mahasiswa (8,90\%), Program Studi Pariwisata Budaya dan Keagamaan sebanyak 38 orang (8,60\%), Program Studi Sosiologi Agama sebanyak 33 mahasiswa (7,50\%), Program Studi Pendidikan Musik Gereja sebanyak 24 mahasiswa (5,5\%), Program Studi Pendidikan Kristen Anak Usia Dini (PKAUD) sebanyak 22 mahasiswa (4,8\%), Program Studi Pastoral Konseling sebanyak 13 mahasiswa (3\%) dan Program Studi Kepemimpinan Kristen sebanyak 7 mahasiswa (1,6\%).

\section{Hasil Penelitian}

Penggunaan handphone/smartphone sebagai perangkat media belajar daring/online sangat dominan, dengan penggunaan pada 419 mahasiswa $(95,20 \%)$, sebaliknya penggunaan laptop/komputer hanya 21 mahasiswa (4,80\%). Penggunaan laptop/komputer pada Program Studi Manajemen Pendidikan sebanyak 3 mahasiswa (7,70\%), kemudian Program Studi Teologi sebanyak 4 mahasiswa (7,50\%), Pendidikan Agama Kristen sebanyak 13 mahasiswa (6,10\%) dan Program Studi Sosiologi Agama sebanyak 1 mahasiswa (3,00\%). 
Pada aspek jenis kelamin, pengguna handphone/smartphone pada 95 mahasiswa laki-laki $(94,10 \%)$ dan pada 324 mahasiswa perempuan $(95,60 \%)$, sedangkan pengguna laptop/komputer oleh 6 mahasiswa laki-laki (5,90\%) dan 15 mahasiswa perempuan $(4,40 \%)$. Pada umumnya mahasiswa yang belajar daring/online dari rumah sendiri/orangtua yaitu pada 335 mahasiswa $(76,14 \%)$, belajar daring/online dari rumah saudara/kerabat pada 42 mahasiswa $(9,55 \%)$, rumah kost/sewa pada 40 mahasiswa $(9.09 \%)$, asrama/kampus pada 17 mahasiswa $(3,86 \%)$ dan belajar daring/online dari fasilitas lain pada 6 mahasiswa $(1,36 \%)$. Fasilitas lain adalah Rumah kontrak/Rumah saudara yang kosong tidak digunakan/rumah teman/tempat kerja: teras restaurant dan café/ tempat kerja (di rumah atasan).

Gambar 1. Persentase (\%) Penggunaan perangkat Media Belajar Daring/online mahasiswa IAKN Tarutung dibedakan menurut Program Studi tahun 2020

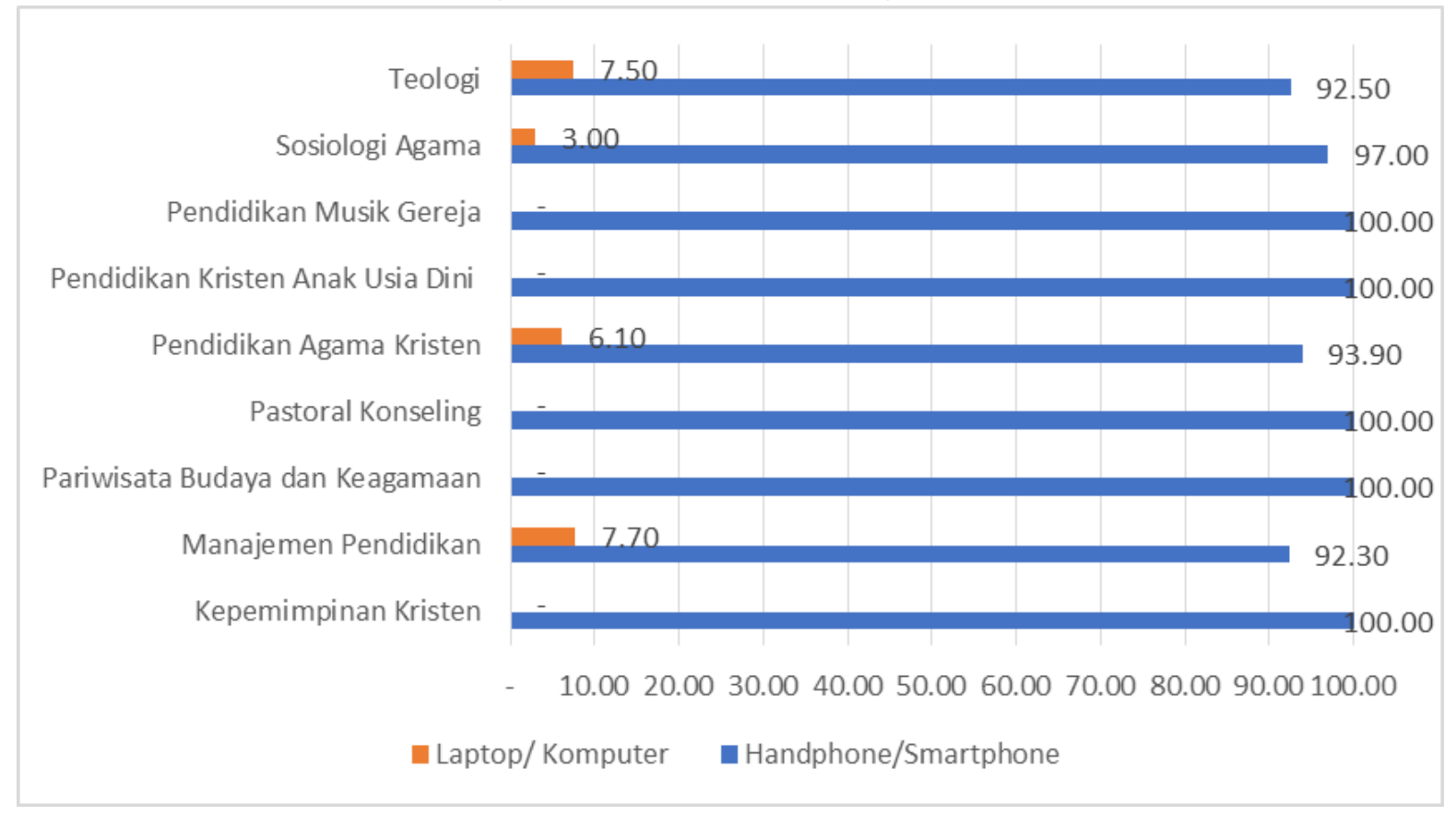

Sumber : Data Primer diolah, 2021.

Pola penggunaan aplikasi belajar daring/online didominasi oleh penggunaan zoom meeting oleh 186 mahasiswa (42,27\%). google meeting oleh 87 mahasiswa (19,77\%). whatsapp group oleh 47 mahasiswa (10,68\%). google classroom oleh 26 mahasiswa $(5,91 \%)$, e-learning oleh 8 mahasiswa $(1,82 \%)$ dan kombinasi dari semua aplikasi oleh 86 mahasiswa $(19,55 \%)$. Berdasarkan aspek keefektifan penggunaan aplikasi dalam pembelajaran daring/online menurut persepsi mahasiswa, aplikasi whatsapp group dipilih sebanyak 169 orang $(38,41 \%)$, google meeting sebanyak 92 orang $(20,91 \%)$. zoom meeting sebanyak 83 orang $(18,86 \%)$, google Classroom sebanyak 67 orang $(15,23 \%)$, e-learning sebanyak 8 orang $(1,82 \%)$ dan kombinasi dari semua aplikasi sebanyak 21 orang $(4,77 \%)$. Berdasarkan data tersebut diatas menunjukkan bahwa pola penggunaan aplikasi belajar daring/online didominasi oleh penggunaan zoom meeting berbeda dengan persepsi mahasiswa terkait aspek keefektifan penggunaan aplikasi dalam pembelajaran daring/online yaitu dengan penggunaan aplikasi whatsapp group. 
Tabel 1. Frekuensi Penggunaan Aplikasi yang digunakan dibandingkan dengan yang dianggap ekfektif dalam Pembelajaran Daring/online mahasiswa IAKN Tarutung tahun 2020

\begin{tabular}{|c|c|c|c|c|c|}
\hline \multirow[t]{2}{*}{ No } & \multirow[t]{2}{*}{ Jenis Aplikasi } & \multicolumn{2}{|c|}{$\begin{array}{c}\text { Aplikasi yang } \\
\text { digunakan }\end{array}$} & \multicolumn{2}{|c|}{$\begin{array}{c}\text { Aplikasi yang } \\
\text { efektif }\end{array}$} \\
\hline & & $\mathrm{n}$ & $\%$ & $\mathrm{n}$ & $\%$ \\
\hline 1 & Zoom Meeting & 186 & 42,27 & 83 & 18,86 \\
\hline 2 & Google Meeting & 87 & 19,77 & 92 & 20,91 \\
\hline 3 & Whatsapp Group & 47 & 10,68 & 169 & 38,41 \\
\hline 4 & Google Classroom & 26 & 5,91 & 67 & 15,23 \\
\hline 5 & Electronic Learning & 8 & 1,82 & 8 & 1,82 \\
\hline & $\begin{array}{l}\text { Kombinasi Zoom Meeting, Google } \\
\text { Meeting, Whatsapp, Google } \\
\text { Classroom, Electronic learning }\end{array}$ & 86 & 19,55 & 21 & 4,77 \\
\hline & Jumlah & 440 & 100,00 & 440 & 100,00 \\
\hline
\end{tabular}

Sumber : Data Primer diolah, 2021.

Persepsi mahasiswa terhadap interaksi antar pengajar dan mahasiswa dalam pembelajaran/ perkuliahan daring/online berada pada kategori sangat baik oleh 93 mahasiswa $(21,14 \%)$, kemudian kategori baik oleh 286 mahasiswa $(65,00 \%)$. kategori ragu-ragu oleh 36 mahasiswa $(8,18 \%)$, kategori tidak baik oleh 20 mahasiswa $(4,55 \%)$ dan kategori sangat tidak baik oleh 5 mahasiswa $(1,14 \%)$. Walaupun demikian berbeda halnya dengan persepsi kemudahan belajar/kuliah daring/online, persepsi mahasiswa dengan kategori sangat baik pada 11 mahasiswa $(2,50 \%)$, kategori baik pada 147 mahasiswa $(33,41 \%)$. kategori raguragu pada 80 mahasiswa $(18,18 \%)$. kategori tidak baik pada 170 mahasiswa $(40,68 \%)$ dan kategori sangat tidak baik pada 23 mahasiswa $(5,23 \%)$. Data tersebut diatas menunjukkan temuan penting bahwa persepsi mahasiswa terhadap interaksi antar pengajar dan mahasiswa dalam pembelajaran/perkuliahan daring/online berada pada kategori sangat baik dan baik tinggi $(86,14 \%)$, tetapi sebaliknya berbeda halnya dengan persepsi kemudahan belajar/kuliah daring/online yang rendah dengan hanya 35,91\% pada kategori sangat baik dan baik.

Persepsi pemahaman kuliah/belajar daring/online persepsi mahasiswa dengan kategori sangat baik pada 10 mahasiswa (2.27\%). kategori baik pada 255 mahasiswa $(57,95 \%)$, kategori ragu-ragu pada 132 mahasiswa (30,00\%), kategori tidak baik pada 33 mahasiswa $(7,50 \%)$ dan kategori sangat tidak baik pada 10 mahasiswa $(2,27 \%)$. Walaupun demikian berbeda halnya dengan persepsi mahasiswa terhadap kesan kuliah/belajar daring/online dengan kategori sangat baik pada 5 mahasiswa (1,14\%), kategori baik pada 125 mahasiswa $(28,41 \%)$. kategori ragu-ragu pada 79 mahasiswa (17,95\%), kategori tidak baik pada 200 mahasiswa $(45,45 \%)$ dan kategori sangat tidak baik pada 31 mahasiswa $(7,05 \%)$. Data tersebut diatas menunjukkan temuan penting bahwa persepsi pemahaman kuliah/belajar daring/online mahasiswa dengan kategori sangat baik dan baik tinggi (60,22\%), tetapi mempunyai kesan kuliah/belajar daring/online dengan kategori sangat baik dan baik yang rendah $(29,62 \%)$. Persepsi mahasiswa terhadap kualitas kuliah/belajar daring/online dengan kategori sangat baik pada 48 mahasiswa $(10,91 \%)$ kategori baik pada 296 mahasiswa $(67,27 \%)$, kategori ragu-ragu pada 81 mahasiswa (18,41\%), kategori tidak baik pada 15 mahasiswa $(2,95 \%)$ dan kategori sangat tidak baik pada 2 mahasiswa $(0,45 \%)$. 
Gambar 2. Persentase (\%) Persepsi terhadap Interaksi dan Kualitas Perkuliahan secara daring/online mahasiswa IAKN Tarutung tahun 2020

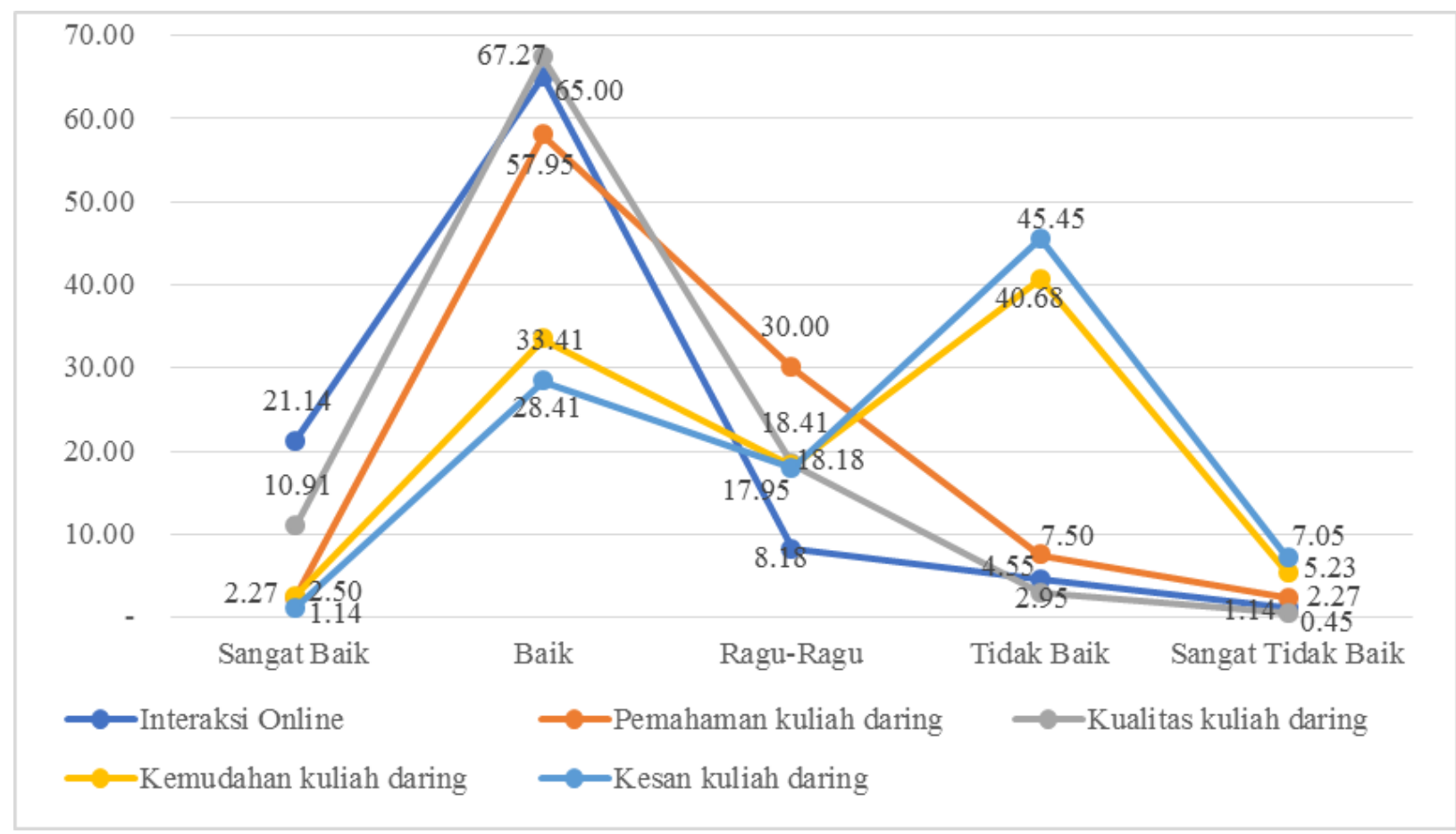

Sumber : Data Primer diolah, 2021.

Pola perkuliahan daring/online yang dilakukan oleh dosen/staf pengajar didominasi dengan cara tunggal terutama penjelasan online langsung pada 124 mahasiswa $(28,18 \%)$, berdiskusi pada forum/chat group pada 50 mahasiswa (11,36\%), diberikan tugas baca pada 16 mahasiswa $(3,64 \%)$ dan diberikan referensi video pada 6 mahasiswa $(1,36 \%)$, total pola perkuliahan daring/online dengan cara tunggal diberikan pada 44,54\% mahasiswa. Temuan penting ini menunjukkan bahwa pola perkuliahan daring/online yang dilakukan oleh dosen/staf pengajar dengan cara tunggal yang tinggi, hal ini diduga karena pemahaman terhadap pemanfaatan aplikasi atau ketersediaan perangkat media belajar dari dosen/staf pengajar yang terbatas.

Pola perkuliahan daring/online yang dilakukan oleh dosen/staf pengajar didominasi dengan cara beragam terutama kombinasi diberikan tugas baca; penjelasan online langsung; memberikan referensi video; pertanyaan/latihan untuk diselesaikan; berdiskusi pada forum/chat group pada 64 mahasiswa (14,55\%). Pola perkuliahan daring/online lainnya dilakukan secara beragam kombinasi antara 2-4 dari pola diberikan tugas baca; penjelasan online langsung; memberikan referensi video; pertanyaan/latihan untuk diselesaikan; berdiskusi pada forum/chat group, terutama pola kombinasi penjelasan online langsung; pertanyaan/latihan untuk diselesaikan; berdiskusi pada forum/chat group pada 32 mahasiswa $(7,27 \%)$ dan pola kombinasi diberikan tugas baca; penjelasan online langsung; pertanyaan/latihan untuk diselesaikan; berdiskusi pada forum/chat group 25 mahasiswa $(5,68 \%)$. 
Tabel 2. Persentase (\%) Pola Perkuliahan Online mahasiswa IAKN Tarutung tahun 2020

\begin{tabular}{|c|c|c|c|}
\hline No & Kegiatan & $\mathrm{n}$ & $\%$ \\
\hline 1 & Berdiskusi pada forum/chat group & 50 & 11,36 \\
\hline 2 & Penjelasan online langsung & 124 & 28,18 \\
\hline 3 & Berdiskusi pada forum/chat group; Penjelasan online langsung & 26 & 5,91 \\
\hline 4 & Penjelasan online langsung; pertanyaan/latihan untuk diselesaikan & 9 & 2,05 \\
\hline 5 & $\begin{array}{l}\text { Penjelasan online langsung; pertanyaan/latihan untuk diselesaikan; } \\
\text { Berdiskusi pada forum/chat group }\end{array}$ & 32 & 7,27 \\
\hline 6 & Penjelasan online langsung; Memberikan referensi video & 4 & 0,91 \\
\hline 7 & $\begin{array}{l}\text { Penjelasan online langsung; Memberikan referensi video; Berdiskusi } \\
\text { pada forum/chat group }\end{array}$ & 6 & 1,36 \\
\hline 8 & $\begin{array}{l}\text { Diberikan tugas baca; penjelasan online langsung; Memberikan referensi } \\
\text { video; pertanyaan/latihan untuk diselesaikan; Berdiskusi pada forum/chat } \\
\text { group }\end{array}$ & 64 & 14,55 \\
\hline 9 & $\begin{array}{l}\text { Penjelasan online langsung; Memberikan referensi video; } \\
\text { pertanyaan/latihan untuk diselesaikan }\end{array}$ & 6 & 1,36 \\
\hline 10 & $\begin{array}{l}\text { Penjelasan online langsung; Memberikan referensi video; } \\
\text { pertanyaan/latihan untuk diselesaikan; Berdiskusi pada forum/chat group }\end{array}$ & 13 & 2,95 \\
\hline 11 & Pertanyaan/latihan untuk diselesaikan & 10 & 2,27 \\
\hline 12 & Pertanyaan/latihan untuk diselesaikan; Berdiskusi pada forum/chat group & 4 & 0,91 \\
\hline 13 & Memberikan referensi video & 6 & 1,36 \\
\hline 14 & Diberikan tugas baca & 16 & 3,64 \\
\hline 15 & Diberikan tugas baca; penjelasan online langsung & 4 & 0,91 \\
\hline 16 & $\begin{array}{l}\text { Diberikan tugas baca; penjelasan online langsung; Berdiskusi pada } \\
\text { forum/chat group }\end{array}$ & 7 & 1,59 \\
\hline 17 & $\begin{array}{l}\text { Diberikan tugas baca; penjelasan online langsung; pertanyaan/latihan } \\
\text { untuk diselesaikan }\end{array}$ & 4 & 0,91 \\
\hline 18 & $\begin{array}{l}\text { Diberikan tugas baca; penjelasan online langsung; pertanyaan/latihan } \\
\text { untuk diselesaikan; Berdiskusi pada forum/chat group }\end{array}$ & 25 & 5,68 \\
\hline 19 & $\begin{array}{l}\text { Diberikan tugas baca; pertanyaan/latihan untuk diselesaikan; Berdiskusi } \\
\text { pada forum/chat group }\end{array}$ & 3 & 0,68 \\
\hline \multirow[t]{2}{*}{20} & Kombinasi tugas & 27 & 6,14 \\
\hline & Jumlah & 440 & 100,00 \\
\hline
\end{tabular}

Sumber : Data Primer diolah, 2021.

Persetujuan mahasiswa untuk selalu dilakukan perkuliahan daring/online di masa depan adalah sangat setuju pada 16 mahasiswa $(3,64 \%)$ dan 39 mahasiswa $(8,86 \%)$ menyatakan setuju, artinya yang menyatakan sangat setuju dan setuju hanya pada $12,50 \%$. Sedangkan yang ragu-ragu pada 57 mahasiswa (12,95\%), sangat tidak setuju pada 115 mahasiswa $(26,14 \%)$ dan tidak setuju pada 215 mahasiswa $(48,41 \%)$ artinya yang menyatakan sangat tidak setuju dan tidak setuju perkuliahan daring/online dilakukan di masa depan sebesar $74,65 \%$.

Ketidak-setujuan terhadap perkuliahan daring/online mahasiswa terutama disebabkan karena akses internet lambat menurut 137 mahasiswa $(31,14 \%)$, keterbatasan kuota internet menurut 107 mahasiswa (24,32\%), kesulitan memahami materi perkuliahan yang diberikan karena tidak bertatap muka langsung dengan dosen/pengajar menurut 107 mahasiswa $(24,32 \%)$, kemudian perangkat (HP/smartphone/laptop/komputer) tidak memadai dan tidak terbiasa kuliah daring/ online masing-masing pada 46 mahasiswa $(10,45 \%)$ dan 8 mahasiswa $(1,82 \%)$. 
Tabel 3. Persentase (\%) Hambatan Perkuliahan Online mahasiswa IAKN Tarutung tahun 2020

\begin{tabular}{rlrr}
\hline No & \multicolumn{1}{c}{ Hambatan Perkuliahan daring/Online } & $\mathrm{n}$ & \multicolumn{1}{c}{$\%$} \\
\hline 1 & Akses Internet Lambat & 137 & 31,14 \\
2 & Kesulitan memahami materi perkuliahan yang diberikan karena tidak & 107 & 24,32 \\
& bertatap muka langsung dengan Dosen/Pengajar & & \\
3 & Keterbatasan Kuota Internet & 107 & 24,32 \\
4 & Perangkat (HP/Smartphone/Laptop/Komputer) tidak memadai & 46 & 10,45 \\
5 & Tidak terbiasa kuliah daring/online & 8 & 1,82 \\
6 & Akses Internet lambat, keterbatasan kuota internet, Kesulitan & 7,95 \\
& memahami materi perkuliahan yang diberikan karena tidak bertatap & & \\
& muka langsung dengan Dosen/pengajar, tidak terbiasa kuliah \\
& daring/online; perangkat tidak memadai; tidak terbiasa online; jaringan \\
& bermasalah & & \\
Jumlah & 440 & 100,00 \\
\hline
\end{tabular}

Sumber : Data Primer diolah, 2021.

\section{Pemanfaatan Aplikasi Media Belajar daring/Online}

Pola penggunaan handphone/smartphone sebagai perangkat media belajar daring/online sangat dominan dan sebaliknya penggunaan laptop/komputer sangat sedikit dan pada umumnya pembelajaran daring/online dilakukan dari rumah sendiri/orangtua, serta tidak berbeda pola menurut jenis kelamin. Temuan penting ini menunjukan bahwa pembelajaran mahasiswa IAKN Tarutung di rumah dominan menggunakan handphone/smartphone yang mudah digunakan tetapi terbatas terutama dalam distribusi data dibandingkan laptop/komputer. Handphone/smartphone memiliki mobilitas yang tinggi dan dapat dioperasikan secara lebih efektif. Hal ini sesuai dengan penelitian Ismanto, Novalia dan Herlandy (2017) bahwa handphone/smartphone merupakan salah satu aplikasi teknologi informasi yang sangat diminati oleh masyarakat. Dalam pelaksanaan kuliah/belajar online, indeks persentase menunjukkan bahwa $76,14 \%$ mahasiswa melaksanakan belajar online dari rumah sendiri/orangtua. Penelitian Handarini dan Wulandari (2020) menunjukkan sejak diberlakukannya kebijakan pemerintah dalam Pembatasan Sosial Berskala Besar (PSBB), maka segala aktifitas termasuk pelaksanaan pembelajaran wajib dilakukan di rumah (study from home).

Selain indeks persentase penggunaan perangkat dan lokasi belajar, persentase penggunaan aplikasi belajar daring/online menunjukkan bahwa aplikasi zoom meeting yang paling sering digunakan oleh dosen/staf pengajar yaitu sebesar 42,27\%. Penelitian Rosyid, Thohari dan Lismanda (2020) menujukkan bahwa penggunaan aplikasi zoom meeting dalam kegiatan mengajar sangat efektif dalam hal waktu dan tempat. Dari sudut pandangan mahasiswa, aplikasi whatsapp group adalah aplikasi yang paling efektif dalam belajar daring/online. Indeks persentase penggunaan whatsapp group sebesar 38,41\%. Hal ini juga sesuai dengan penelitian Mustami, Paridjo dan Utami (2020); Saragih dan Ansi (2020) bahwa whatsapp group dapat dijadikan sebagai media komunikasi/diskusi antara dosen/staf pengajar dengan mahasiswa dan dengan mudah bisa mengirim balik hasil pekerjaan, baik berupa komentar langsung (chat group), gambar, video atau soft files lainnya yang berhubungan dengan pembelajaran. Temuan penting terkait penggunaan aplikasi belajar daring/online menunjukkan bahwa penggunaan zoom meeting belum dianggap familiar oleh mahasiswa dibandingkan dengan penggunaan aplikasi whatsapp group yang telah dikenalnya dalam kehidupan sehari-hari sebagai media sosial. 


\section{Interaksi, Kualitas dan Hambatan Perkuliahan Daring/Online}

Persepsi mahasiswa terhadap kualitas kuliah/belajar daring/online dengan kategori sangat baik dan baik yang tinggi $(78,18 \%)$, hal ini dapat disebabkan karena interaksi antar pengajarmahasiswa dan pemahaman dalam pembelajaran/perkuliahan daring/online yang dipersepsikan baik. Tetapi sebaliknya persepsi mahasiswa terhadap kemudahan dan kesan belajar/kuliah daring/online yang cukup rendah, hal ini kemungkinan pola pelaksanaan perkuliahan daring/online masing dilakukan dengan cara tunggal yaitu penjelasan online langsung $(28,18 \%)$, berdiskusi pada forum/chat group $(11,36 \%)$, diberikan tugas baca $(3,64 \%)$ dan diberikan referensi video $(1,36 \%)$, total pola perkuliahan daring/online dengan cara tunggal diberikan pada 44,54\% mahasiswa.

Temuan penting tersebut menunjukkan bahwa pola perkuliahan daring/online yang dilakukan oleh dosen/staf pengajar dengan cara tunggal yang tinggi, hal ini diduga karena pemahaman terhadap pemanfaatan aplikasi atau ketersediaan perangkat media belajar dari dosen/staf pengajar yang terbatas dan kurang inovatif. Pola perkuliahan daring/online tunggal dan tidak variatif akan membosankan dan menimbulkan persepsi kualitas perkuliahan online tidak baik serta mahasiswa juga kurang termotivasi untuk meningkatkan prestasi belajar. Hal ini sesuai juga dengan penelitian Yuniarti (2010) yang menyatakan bahwa kekurangan dari pembelajaran daring/online adalah a) kurangnya interaksi sehingga menurunkan fungsi manusia sebagai mahkluk sosial, b) tidak mengakomodasi praktek yang harus tatap muka, c) kurangnya interaksi dapat memperlambat terbentuknya tata nilai/values dalam proses belajar dan mengajar, d) cenderung mengabaikan aspek akademik dan sosial tetapi mendorong tumbuhnya aspek bisnis dan e) peserta dengan motivasi belajar rendah cenderung gagal.

Ketidaksetujuan mahasiswa terhadap perkuliahan daring/online di masa depan terutama disebabkan karena akses internet lambat, keterbatasan kuota internet, kesulitan memahami materi perkuliahan yang diberikan karena tidak bertatap muka langsung dengan dosen/pengajar, kemudian perangkat (handphone/smartphone/laptop/komputer) tidak memadai dan tidak terbiasa kuliah daring/online. Hal ini sesuai dengan penelitian Hapsari dan Fitria (2020) bahwa pembelajaran daring/online dengan materi yang terstruktur akan lebih efektif. Sadikin dan Hamidah (2020) menyatakan bahwa akses internet lambat dan keterbatasan kuota internet menjadi hambatan utama mahasiswa ketika mereka belajar dari rumah.

\section{KESIMPULAN DAN SARAN}

\section{Kesimpulan}

1. Pola penggunaan handphone/smartphone sebagai perangkat media belajar daring/online sangat dominan dan sebaliknya penggunaan laptop/komputer sangat sedikit dan pada umumnya pembelajaran daring/online dilakukan dari rumah sendiri/orangtua, serta tidak berbeda pola menurut jenis kelamin. Penggunaan zoom meeting dalam pembelajaran daring/online oleh dosen/staf pengajar belum dianggap familiar oleh mahasiswa dibandingkan dengan penggunaan aplikasi whatsapp group yang telah dikenalnya dalam kehidupan sehari-hari sebagai media sosial.

2. Persepsi mahasiswa terhadap kualitas kuliah/belajar daring/online baik, hal ini dapat disebabkan karena interaksi antar pengajar-mahasiswa dan pemahaman dalam pembelajaran/perkuliahan daring/online yang dipersepsikan baik. Tetapi sebaliknya persepsi mahasiswa terhadap kemudahan dan kesan belajar/kuliah daring/online yang cukup rendah, hal ini kemungkinan pola pelaksanaan perkuliahan daring/online masih dominan dilakukan dengan cara tunggal dengan hanya melakukan penjelasan online langsung, atau hanya berdiskusi pada forum/chat group, atau hanya memberikan tugas baca atau memberikan referensi video. 


\section{Saran}

1. Diperlukan inovasi dalam materi pembelajaran interaktif dari pengajar dan penyelenggara sehingga pembelajaran mudah diakses melalui perangkat handphone, serta menggunakan aplikasi yang aman dan tidak tunggal dengan alternatif aplikasi lain sehingga pembelajaran tetap berlangsung jika ada kendala di satu aplikasi.

2. Diperlukan inovasi dan perencanaan metode pembelajaran yang interaktif sehingga mahasiswa dapat berinteraksi secara aktif, mudah memahami materi yang disampaikan, sesuai dengan tujuan pembelajaran dan pemberian fasilitasi kemudahan mahasiswa untuk mengakses internet. Terkait dengan keterbatasan akses internet di Kota Tarutung untuk dapat diakses disarankan untuk membuat penjadwalan pembelajaran daring/online sehingga kapasitas bandwidth dapat di kelola dengan optimal, terkait dengan keterbatasan kuota internet pada mahasiswa diperlukan fasilitasi oleh manajemen kampus terhadap kemudahan mahasiswa dalam mengakses internet.

\section{DAFTAR PUSTAKA}

Adijaya, N., dan Santosa, L. P. (2018). Persepsi Mahasiswa Dalam Pembelajaran Online. Wanastra, 10(2), 105-110.

Anugrahana, A. (2020). Hambatan, Solusi dan Harapan: Pembelajaran Daring Selama Masa Pandemi Covid-19 Oleh Guru Sekolah Dasar. Scholaria: Jurnal Pendidikan dan Kebudayaan, 10(3), September 2020, 282-289.

Astuti, P., dan Febrian, F. (2019). Blended Learning Syarah: Bagaimana Penerapan dan Persepsi Mahasiswa. Jurnal Gantang, 4(2), 111-119. https ://doi.org/10.31629/ jg.v4i2.1560.

Handarini, OI dan Wulandari, SS. (2020). Pembelajaran Daring Sebagai Upaya Study From Home (SFH) Selama Pandemi Covid 19. Jurnal Pendidikan Administrasi Perkantoran (JPAP), 8(3), 496-503.

Hapsari, TPRN. dan Fitria, AS. (2020). Efektivitas Pembelajaran Daring Mata Kuliah Evaluasi Pengajaran Bahasa dan Sastra Indonesia Masa Pandemi Covid-19. Jurnal Ilmiah SEMANTIKA, 2(1), 11-20.

Iftakhar, S. (2016). Google Classroom: What Works and How? Journal of Education and Social Sciences, 3, 12-18.

Ismanto, E, Novalia, M dan Herlandy, PB. (2017). Pemanfaatan Smartphone Android Sebagai Media Pembelajaran Bagi Guru SMA Negeri 2 Kota Pekanbaru. JURNAL Untuk Mu negeRI, 1(1), Mei 2017, 42-47.

Kumar V and Nanda P. (2019). Social Media in Higher Education. International Journal of Information and Communication Technology Education (IJICTE). 2019;15(1): 97-108. https://doi.org/10.4018/ijicte.2019010107.

Maulana, HA. dan Hamidi, M. (2020). Persepsi Mahasiswa terhadap Pembelajaran Daring pada Mata Kuliah Praktik di Pendidikan Vokasi. Equilibrium: Jurnal Pendidikan, 8(2), 224-231.

Muhyiddin. (2020). Covid-19, New Normal dan Perencanaan Pembangunan di Indonesia. The Indonesian Journal of Development Planning, 4(2), 240-252.

Mustami, SS., Paridjo dan Wikan, BU. (2020). Efektivitas Pembelajaran Melalui Whatsapp Grup Terhadap Kemampuan Pemecahan Masalah Matematika. Jurnal Pendidikan Surya Edukasi (JPSE), 6(2), 175-186.

Naserly MK, (2020). Implementasi Zoom, Google Classroom, Dan Whatsapp Group Dalam Mendukung Pembelajaran Daring (Online) Pada Mata Kuliah Bahasa Inggris Lanjut (Studi Kasus Pada 2 Kelas Semester 2, Jurusan Administrasi Bisnis, Fakultas Ekonomi 
dan Bisnis, Universitas Bina Sarana Informatika Jakarta. Edutech Consultant Bandung ; Jurnal Aksara Public. Vol. 4 No. 2 Edisi Mei 2020, 155-165.

Rosyid, NM, Thohari, I. dan Lismanda, YF. (2020). Penggunaan Aplikasi Zoom Cloud Meetings Dalam Kuliah Statistik Pendidikan Di Fakultas Agama Islam Universitas Islam Malang. Vicratina: Jurnal Pendidikan Islam, 5(11), 46-52.

Sadikin A. dan Hamidah A. (2020). Pembelajaran Daring di Tengah Wabah Covid-19. Program Studi Pendidikan Biologi FKIP Universitas Jambi, 6(02), 215-224.

Santoso S. (2019). Menguasai Statistik dengan SPSS 25. Jakarta : Elex Media Komputindo Kompas Gramedia. 467p.

Saragih, EM. dan Ansi, RY. (2020). Efektivitas Penggunaan Whatsapp Group Selama Pandemi Covid-19 Bagi Pelaku Pendidik. Prosiding Seminar Nasional Multidisiplin Ilmu Universitas Asahan ke-4 Tahun 2020, 207-212.

So, S. (2016). Mobile instant messaging support for teaching and learning in higher education. Internet and Higher Education. The Internet and Higher Education. Vol. 31, October 2016, Pages 32-42. https://doi.org/10.1016Zj.iheduc.2016.06.001.

Yuniarti, RD. (2010). Potensi E-Learning Melalui Sistem Kuliah On-Line Dalam Meningkatkan Kualitas Pembelajaran Di Prodi Tata Niaga Jurusan Pendidikan Ekonomi FPEB-UPI. Jurnal Manajerial, 8(16), 66-77. 